\title{
Effects of sodium nitroprusside upon cardiac work, efficiency, and substrate extraction in severe left ventricular failure
}

\author{
D S THOMPSON, S M JUUL, P WILMSHURST, N NAQVI, D J COLTART, \\ B S JENKINS, M M WEBB-PEPLOE
}

From the Departments of Cardiology and Medicine, St Thomas's Hospital, London

SUMMARY In nine patients with severe left ventricular failure caused by coronary artery disease or congestive cardiomyopathy, left ventricular pressure, cardiac output, coronary sinus blood flow, and myocardial substrate extraction were measured before and during infusion of sodium nitroprusside. Infusion of $55 \mu \mathrm{g} / \mathrm{min}$ reduced left ventricular systolic and end-diastolic pressures, peripheral resistance, coronary sinus flow, and myocardial oxygen consumption. Left ventricular minute work increased slightly, but the large improvement in myocardial efficiency was mainly the result of decreased oxygen consumption. Doubling the infusion rate to $110 \mu \mathrm{g} / \mathrm{min}$ caused no further decrease in ventricular pressures depite further reduction of peripheral resistance; as myocardial oxygen consumption did not change, the further improvement in efficiency was due to increased external work, the result of increased stroke volume. Thus, nitroprusside appears to improve efficiency in low dose by reducing load (ventricular pressure and volume decrease) and in high dose by increasing work at constant load.

The large reduction in coronary sinus flow during the infusion of $55 \mu \mathrm{g} / \mathrm{min}$ did not provoke angina or lactate production, and thus reflected decreased myocardial oxygen demand and not inadequate perfusion pressure. The improvement in efficiency during nitroprusside infusion was not accompanied by significant changes in arterial concentration, extraction ratio, or oxygen extraction ratio of any of the substrates measured, and substrate consumption fell in proportion to coronary flow. Six patients performed isometric exercise during and after nitroprusside infusion. Off nitroprusside exercise increased heart rate, systolic pressure, and peripheral resistance; end-diastolic pressure rose in five patients. Myocardial oxygen consumption increased proportionately more than work to produce a small but significant decrease in efficiency. Exercise during nitroprusside infusion did not increase heart rate and peripheral resistance significantly, but end-diastolic pressure and myocardial oxygen consumption rose substantially, causing a large reduction in efficiency. Thus, though nitroprusside improves the performance of the failing heart, the gain in efficiency is precarious, and is substantially eroded by the stress of isometric exercise.

Drugs which act primarily upon the peripheral circulation may improve the performance of the failing heart. ${ }^{12}$ Sodium nitroprusside is a potent venous and arterial dilator, ${ }^{3}$ and its rapid onset and short duration of action allow its effects to be studied during diagnostic cardiac catheterisation. The response to the drug in individual patients may predict the efficacy of oral vasodilator therapy. ${ }^{4}$ Previous studies demonstrate considerable variation between patients in the haemodynamic changes and the dose of nitroprusside that can be tolerated before blood pressure falls to unacceptable levels. ${ }^{56}$ In Received for publication 4 June 1981 general, patients with severe failure sustain the most benefit, and tolerate high doses without precipitous reduction of blood pressure. ${ }^{6}$ For this study we selected patients who had clinical and haemodynamic evidence of severe left ventricular failure and who might, therefore, all have similar responses to nitroprusside and tolerate the same dose. In addition, the effects of the drug were of direct relevance to the future management of each patient.

The haemodynamic effects of nitroprusside are well documented ${ }^{4}{ }^{6}$ but there is less information about its effects upon myocardial oxygen consumption and substrate extraction. Measurement of myocardial 
oxygen consumption allows the estimation of myocardial efficiency, ${ }^{7}$ which from theoretical considerations ${ }^{8}$ may be useful in assessing the consequences of changes in loading conditions.

In this report we describe the effects of nitroprusside infusion at rest and during isometric exercise in patients with severe left ventricular disease, with particular reference to work, myocardial oxygen consumption, and efficiency. Myocardial lactate extraction was measured to investigate the effects of nitroprusside upon the balance between oxygen supply and demand. ${ }^{9}{ }^{10}$ Extraction of other substrates was measured to determine whether changes in myocardial energy consumption and efficiency were associated with metabolic changes.

\section{Patients and methods}

Nine male patients (ages 18 to 56) were studied. All were limited by dyspnoea and had clinical evidence of severe heart failure despite treatment with bed rest and diuretics. The nature and purpose of the investigation was explained, and each patient gave written consent.

All studies were performed after an overnight fast. One hour before catheterisation atropine $0.6 \mathrm{mg}$ and diazepam $10 \mathrm{mg}$ were given intramuscularly, and heparin $45 \mathrm{units} / \mathrm{kg}$ was administered intravenously to minimise the effect of a subsequent dose of heparin upon free fatty acid concentrations. ${ }^{11}$ Right and left heart catheterisation was performed via the right femoral vein and artery respectively. A second dose of 45 units/kg heparin was given immediately after arterial catheterisation. After routine pressure measurements and coronary arteriography a Schwarzer Swan Ganz catheter for dye dilution cardiac output determination was positioned in the pulmonary artery, and a Telco (MM52) catheter-tip micromanometer in the left ventricle. A No. $7 \mathrm{Ganz}$ catheter (Wilton-Webster Inc.) was advanced via a left antecubital vein into the coronary sinus, and its position confirmed by injection of contrast. Cold saline was injected into the right atrium to ensure that the dilution thermistor was unaffected by reflux of atrial blood. ${ }^{12}$ Left ventricular pressure, cardiac output, and coronary sinus flow were measured and left ventricular and coronary sinus blood sampled. Using a constant infusion pump, sodium nitroprusside was administered into the pulmonary artery at a rate of $55 \mu \mathrm{g} / \mathrm{min}$. After allowing 15 minutes for stabilisation, measurements and samples were repeated. In seven patients the infusion rate was increased to $110 \mu \mathrm{g} / \mathrm{min}$ and further measurements made. In six patients the $110 \mu \mathrm{g} / \mathrm{min}$ infusion was continued and measurements repeated after three minutes of isometric exercise $(75 \%$ maximal hand grip). The nitroprusside was stopped, and further measurements made at rest and during identical isometric exercise. Substrate concentrations were not measured during exercise because of its effect upon arterial lactate concentration. ${ }^{13}$

The micromanometer signals were displayed on a Cambridge 12 channel recorder, and analysed on line by a Varian computer $(620 / \mathrm{L}-100)$ to yield $\max \mathrm{dP} / \mathrm{dt}$ and $\mathrm{KV}$ max. Mean systolic pressure was derived by planimetric integration of the ventricular pressure trace and used in the calculation of stroke work, minute work, and peripheral resistance. Dye dilution curves were analysed by a Schwarzer IVH 3 cardiac output computer. Coronary sinus blood flow was estimated by constant infusion thermodilution, ${ }^{14}$ and blood oxygen content measured upon a $\mathrm{LEX} \mathrm{\textrm {O } _ { 2 }}$ CON-TL. Blood samples were added to aliquots of perchloric acid for subsequent photometric estimation of lactate and pyruvate, ${ }^{15}$ acetoacetate and hydroxybutyrate $^{16}$ and glycerol, ${ }^{17}$ and to sequestrene tubes for estimation of free fatty acids. ${ }^{18}$

Myocardial oxygen consumption was calculated as coronary sinus flow $\times$ arteriocoronary sinus $\mathrm{O}_{2}$ differences. Cardiac efficiency was estimated as:

LV minute work $(\mathrm{kg} \mathrm{m} / \mathrm{min}) \times 100$ (Normal $=40 \%)$

Myocardial oxygen consumption $\times 2.059 \times 0.806^{7}$

The extraction ratio of a substrate is defined as the difference in concentration between arterial and coronary sinus blood as a percentage of arterial concentration. The oxygen extraction ratio is the oxygen that would be required for complete oxidation of the amount of that substrate extracted expressed as a percentage of measured oxygen extraction.

Statistical analysis was by Student's $t$ test. Values are expressed as mean \pm SEM $(p<0.05$ is considered significant).

\section{Results}

Each of the nine patients studied had evidence of severe left ventricular disease. Their angiographic and basal haemodynamic results are listed in Table 1. Four had normal coronary arteriograms and were diagnosed as having congestive cardiomyopathy. The five patients with coronary artery disease were limited by dyspnoea rather than by angina.

The effects of nitroprusside administration are shown in Fig. 1 and 2. Infusion of $55 \mu \mathrm{g} / \mathrm{min}$ significantly reduced peak left ventricular systolic pressure from $93 \pm 5 \mathrm{mmHg}$ to $81 \pm 3 \mathrm{mmHg}$ $(\mathrm{p}<0.01)$, end-diastolic pressure from $23 \pm 2 \mathrm{mmHg}$ to $11 \pm 3 \mathrm{mmHg}(\mathrm{p}<0.01)$, and peripheral resistance from $31 \pm 4$ units to $25 \pm 4$ units $(p<0.01)$. The changes in heart rate from $107 \pm 7$ to $106 \pm 7$ beats/ $\min , \mathrm{KVmax}$ from $78 \pm 4 / \mathrm{s}$ to $65 \pm 7 / \mathrm{s}$, and $\max \mathrm{dP} / \mathrm{dt}$ from $888 \pm 88 \mathrm{mmHg} / \mathrm{s}$ to $849 \pm 59 \mathrm{mmHg} / \mathrm{s}$ were not 
Table 1 Basal haemodynamics and results of angiography

\begin{tabular}{|c|c|c|c|c|c|c|c|c|c|c|}
\hline $\begin{array}{l}\text { Case } \\
\text { No. }\end{array}$ & $\begin{array}{l}\text { Age } \\
(y)\end{array}$ & $E F$ & $E D V I$ & $C I$ & $L V E D P^{\star}$ & $P R$ & $\mathrm{MVO}_{2}$ & $L V M W$ & $\begin{array}{l}\text { Efficiency } \\
(\%)\end{array}$ & $\begin{array}{l}\text { Coronary } \\
\text { arteriograms }\end{array}$ \\
\hline 1 & 19 & 0.02 & 310 & 0.80 & 18 & 54 & $35 \cdot 2$ & 0.80 & $1 \cdot 4$ & Normal \\
\hline 2 & 18 & 0.12 & 395 & $1 \cdot 24$ & 28 & 30 & $21 \cdot 3$ & 0.62 & $1 \cdot 6$ & Normal \\
\hline 3 & 49 & 0.24 & 228 & 1.37 & 26 & 33 & $15 \cdot 6$ & $2 \cdot 23$ & $8 \cdot 6$ & Normal \\
\hline 4 & 46 & 0.25 & 218 & $1 \cdot 52$ & 16 & 26 & $19 \cdot 0$ & $2 \cdot 50$ & $7 \cdot 4$ & Normal \\
\hline 5 & 54 & 0.35 & 216 & $2 \cdot 05$ & 27 & 15 & $27 \cdot 6$ & $2 \cdot 34$ & $4 \cdot 8$ & $\begin{array}{l}\text { Triple vessel } \\
\text { disease }\end{array}$ \\
\hline 6 & 46 & $0 \cdot 19$ & 247 & 1.93 & 30 & 26 & $17 \cdot 6$ & $2 \cdot 74$ & $9 \cdot 4$ & $\begin{array}{l}\text { Double vessel } \\
\text { disease }\end{array}$ \\
\hline 7 & 49 & $0 \cdot 22$ & 191 & $2 \cdot 07$ & 18 & 24 & $31 \cdot 4$ & 3.90 & $7 \cdot 0$ & $\begin{array}{l}\text { Triple vessel } \\
\text { disease }\end{array}$ \\
\hline 8 & 40 & $0 \cdot 26$ & 191 & 0.94 & 27 & 47 & $8 \cdot 7$ & $1 \cdot 60$ & $11 \cdot 1$ & $\begin{array}{c}\text { Triple vessel } \\
\text { disease }\end{array}$ \\
\hline 9 & 56 & 0.19 & 228 & $2 \cdot 14$ & 21 & 22 & $26 \cdot 3$ & $2 \cdot 72$ & $6 \cdot 2$ & $\begin{array}{c}\text { Triple vessel } \\
\text { disease }\end{array}$ \\
\hline Mean & $41 \cdot 9$ & $0 \cdot 20$ & 247 & $1 \cdot 56$ & 23 & 31 & $22 \cdot 5$ & $2 \cdot 16$ & $6 \cdot 4$ & \\
\hline SEM & $4 \cdot 7$ & 0.03 & 22 & 0.17 & 2 & 4 & $2 \cdot 8$ & 0.34 & $1 \cdot 1$ & \\
\hline
\end{tabular}

EF, ejection fraction; EDVI, end-diastolic volume index $\left(\mathrm{ml} / \mathrm{m}^{2}\right)$; CI, cardiac index $\left(\mathrm{l} / \mathrm{min}\right.$ per $\left.\mathrm{m}^{2}\right)$; LVEDP, left ventricular end-diastolic pressure (mmHg); PR, peripheral resistance (units); $\mathrm{MVO}_{2}$, myocardial oxygen uptake (ml/min); LVMW, left ventricular minute work (kg $\mathrm{m} / \mathrm{min}$ ).

^Sternal angle used as zero reference for all pressure measurements.

significant. Cardiac output increased from $2.87 \pm 0 \cdot 36$ $1 / \mathrm{min}$ to $3.32 \pm 0.441 / \mathrm{min} \quad(p<0.05)$, and left ventricular minute work from $2 \cdot 16 \pm 0.34 \mathrm{~kg} \mathrm{~m} / \mathrm{min}$ to $2.52 \pm 0 \frac{1}{2} 32 \mathrm{~kg} \mathrm{~m} / \mathrm{min} \quad(\mathrm{p}<0.01)$. There were substantial reductions in coronary sinus flow, from $195 \pm 19 \mathrm{ml} / \mathrm{min}$ to $139 \pm 12 \mathrm{ml} / \mathrm{min}(\mathrm{p}<0.01)$ and myocardial oxygen consumption from $22.5 \pm 2.8 \mathrm{ml} /$ $\mathrm{min}$ to $14.2 \pm 1.2 \mathrm{ml} / \mathrm{min}(\mathrm{p}<0.01)$, and efficiency increased from $6.4 \% \pm 1.1$ to $11.5 \% \pm 1.8(p<0.01)$.

In seven patients increasing the infusion rate of nitroprusside to $110 \mu \mathrm{g} / \mathrm{min}$ did not change left ventricular systolic or end-diastolic pressure significantly though there was further reduction of peripheral resistance from $25 \pm 4$ to $18 \pm 4$ units $(p<0.02)$. Cardiac output increased further from $3.32 \pm 0.44 \mathrm{l} / \mathrm{min}$ to $4.23 \pm 0.61 \mathrm{l} / \mathrm{min}(\mathrm{p}<0.01)$ and left ventricular minute work from $2.52 \pm 0.32 \mathrm{~kg} \mathrm{~m} / \mathrm{min}$ to $3.15 \pm 0.5 \mathrm{~kg} \mathrm{~m} / \mathrm{min}(\mathrm{p}<0.01)$. The changes in coronary sinus flow, from $139 \pm 12 \mathrm{ml} / \mathrm{min}$ to $142 \pm 14$ $\mathrm{ml} / \mathrm{min}$, and myocardial oxygen consumption
Fig. 1 Summary of haemodynamic results before and at each dose of nitroprusside. Values expressed as mean \pm SEM. LVSP, left ventricular systolic pressure. LVEDP, left ventricular end-diastolic pressure. ${ }^{\star} p<0.05$ and $\star \star p<0.01$ when control results are compared with results during infusion of $55 \mu \mathrm{g} / \mathrm{min}$ nitroprusside. $t p<0.05$ and $\neq p<0.01$ when results during infusion of $55 \mu \mathrm{g} / \mathrm{min}$ and $110 \mu \mathrm{g} / \mathrm{min}$ are compared.
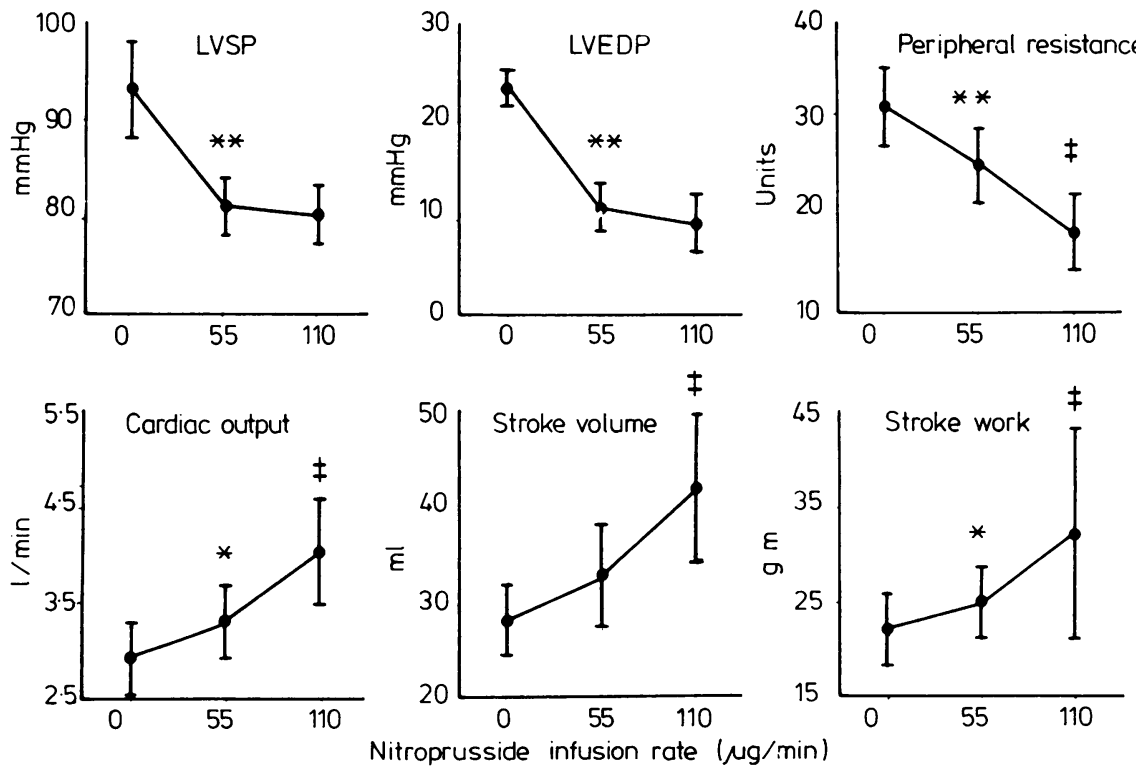

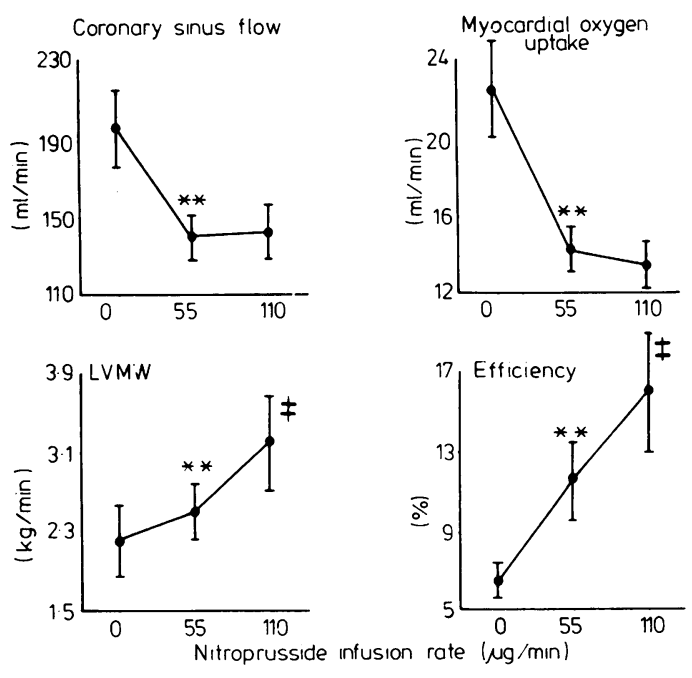

Fig. 2 Mean \pm SEM of coronary sinus blood flow, myocardial oxygen uptake, left ventricular minute work (LVMW) and efficiency during control period and infusion of nitroprusside at 55 and $110 \mu \mathrm{g} / \mathrm{min} .{ }^{\star \star}$ and $\ddagger$ as in Fig. 1 .

from $14 \cdot 2 \pm 1 \cdot 2$ to $13 \cdot 4 \pm 1.4 \mathrm{ml} / \mathrm{min}$ were not significant. Efficiency increased further from $11.5 \% \pm 1.8$ to $16.0 \% \pm 3.1 \quad(\mathrm{p}<0.05)$. Heart rate, $107 \pm 7$ and $106 \pm 6$ beats/min, $\mathrm{KVmax}, 65 \pm 7$ and $57 \pm 8 / \mathrm{s}$, and $\max \mathrm{dP} / \mathrm{dt}, 849 \pm 56$ and $891 \pm 72$ $\mathrm{mmHg} / \mathrm{s}$ were similar at both infusion rates.

The effects of isometric exercise in six patients are illustrated in Fig. 3. Off nitroprusside, exercise increased heart rate from $94 \pm 4$ to $114 \pm 7$ beats/min $(\mathrm{p}<0.02)$, left ventricular systolic pressure from $99 \pm 4$ $\mathrm{mmHg}$ to $112 \pm 7 \mathrm{mmHg}(\mathrm{p}<0.05)$, and peripheral resistance from $26 \pm 5$ units to $33 \pm 5$ units $(p<0.02)$. Cardiac output changed little, and the increase in left ventricular minute work from $2 \cdot 38 \pm 0.20 \mathrm{~kg} \mathrm{~m} / \mathrm{min}$ to $2 \cdot 70 \pm 0.27 \mathrm{~kg} \mathrm{~m} / \mathrm{min}$ was not significant. Coronary sinus flow increased from $168 \pm 18 \mathrm{ml} / \mathrm{min}$ to $250 \pm 42$ $\mathrm{ml} / \mathrm{min}(\mathrm{p}<0.05)$ and myocardial oxygen consumption from $18.3 \pm 3.3 \mathrm{ml} / \mathrm{min}$ to $27.5 \pm 4.8 \mathrm{ml} / \mathrm{min}$ $(p<0.05)$. There was a small, but significant decrease in efficiency from $8.5 \% \pm 0.9$ to $6.9 \% \pm 1.2(\mathrm{p}<0.05)$. Max dP/dt increased from $880 \pm 38$ to $982 \pm 51 \mathrm{mmHg} / \mathrm{s}$ $(\mathrm{p}<0.05)$, and $\mathrm{KVmax}$ from $73 \pm 4$ to $84 \pm 9 / \mathrm{s}$ (NS). When isometric exercise was performed during nitroprusside infusion at $110 \mu \mathrm{g} / \mathrm{min}$ the increase in heart rate from $100 \pm 4$ to $109 \pm 8$ beats $/ \mathrm{min}$ was not significant. Left ventricular systolic pressure increased from $78 \pm 7 \mathrm{mmHg}$ to $87 \pm 2 \mathrm{mmHg}$ $(p<0.05)$ and end-diastolic pressure from $9 \pm 3 \mathrm{mmHg}$ to $18 \pm 4 \mathrm{mmHg}(\mathrm{p}<0.05)$. Cardiac output changed from $4.59 \pm 0.631 / \mathrm{min}$ to $4.41 \pm 0.75 \mathrm{l} / \mathrm{min}$, peripheral resistance from $18 \cdot 4 \pm 5$ units to $21 \cdot 2 \pm 5$ units, and left ventricular minute work from $3.63 \pm 0.35 \mathrm{~kg} \mathrm{~m} / \mathrm{min}$ to $3.17 \mathrm{~kg} \mathrm{~m} / \mathrm{min}$ : these were not significant. The small increases in $\mathrm{KVmax}, 63 \pm 6 / \mathrm{s}$ to $68 \pm 7 / \mathrm{s}$, and $\max$ $\mathrm{dP} / \mathrm{dt}, 843 \pm 72 \mathrm{mmHg} / \mathrm{s}$ to $864 \pm 86 \mathrm{mmHg} / \mathrm{s}$, were not significant. Coronary sinus blood flow increased from $147 \pm 24 \mathrm{ml} / \mathrm{min}$ to $214 \pm 34 \mathrm{ml} / \mathrm{min}(p<0.02)$ and myocardial oxygen consumption from $12 \cdot 7 \pm 2 \cdot 4$ to $19.8 \pm 3.6 \mathrm{ml} / \mathrm{min}(\mathrm{p}<0.01)$, and efficiency decreased from $19 \cdot 5 \% \pm 3 \cdot 2$ to $11 \cdot 2 \% \pm 2 \cdot 5(p<0.05)$.

The patterns of response to nitroprusside, both at rest and on exercise, were similar in patients with cardiomyopathy and coronary artery disease.
Fig. 3 Summary of results before and during isometric exercise. Open circles: off nitroprusside. Closed circles: during infusion of nitroprusside. $H R$, heart rate (beats) min); LVSP, LV systolic pressure (mmHg); LVEDP, $L V$ end-diastolic pressure ( $\mathrm{mmHg}$ ); CO, cardiac output (l/min); $P R$, peripheral resistance (units); CSF, coronary sinus flow ( $\mathrm{ml} / \mathrm{min}) ; \mathrm{MVO}_{2}$, myocardial oxygen consumption ( $\mathrm{ml} / \mathrm{min})$; LVMW, LV minute work ( $\mathrm{kg}$ $\mathrm{m} / \mathrm{min}$ ). Values expressed as mean $\pm S E M .{ }^{\star} p<0.05$ when values at rest are compared with values on exercise off nitroprusside. $t p<0.05$, $\ddagger p<0.01$ when values at rest are compared with values on exercise during nitroprusside infusion.
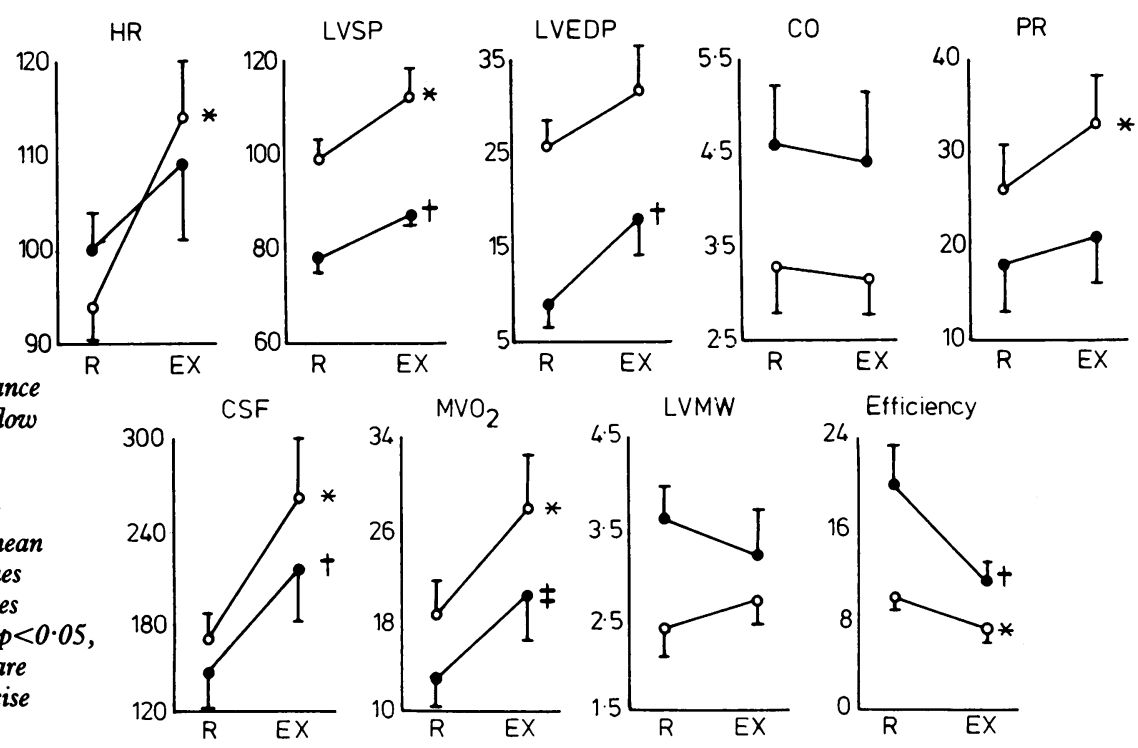
Table 2 Summary of metabolic results

\begin{tabular}{|c|c|c|c|c|c|c|c|c|c|c|c|c|}
\hline & \multicolumn{4}{|c|}{ Cominal $(n=9)$} & \multicolumn{4}{|c|}{ Nitropnusside $55 \mu \mathrm{g} / \min (n=9)$} & \multicolumn{4}{|c|}{ Nitroprusside $110 \mu \mathrm{g} / \min (n=7)$} \\
\hline & (A) & $(C S)$ & $\boldsymbol{E R}$ & $O E R$ & (A) & $(C S)$ & $E R$ & $O E R$ & $(A)$ & $(C S)$ & $E R$ & $O E R$ \\
\hline Lactate & $\begin{array}{r}1.02 \\
\pm 0.23\end{array}$ & $\begin{array}{r}0.670 \\
\pm 0.161\end{array}$ & $\begin{array}{l}34 \cdot 2 \\
\pm 7 \cdot 0\end{array}$ & $\begin{array}{l}23.6 \\
\pm 5.2\end{array}$ & $\begin{array}{r}1.029 \\
\pm 0.29\end{array}$ & $\begin{array}{r}0.640 \\
\pm 0.155\end{array}$ & $\begin{array}{l}33.8 \\
\pm 6.7\end{array}$ & $\begin{array}{l}26 \cdot 2 \\
\pm 7 \cdot 8\end{array}$ & $\begin{aligned} 1.106 \\
\pm 0.33\end{aligned}$ & $\begin{array}{r}0.784 \\
\pm 0.158\end{array}$ & $\begin{array}{l}18.0 \\
\pm 6.5\end{array}$ & $\begin{array}{l}22.9 \\
\pm 13.4\end{array}$ \\
\hline Pyruvate & $\begin{array}{r}0.061 \\
\pm 0.011\end{array}$ & $\begin{array}{r}0.033 \\
\pm 0.006\end{array}$ & $\begin{array}{l}45 \cdot 0 \\
\pm 5 \cdot 3\end{array}$ & $\begin{array}{r}1.6 \\
\pm 0.4\end{array}$ & $\begin{array}{r}0.066 \\
\pm 0.014\end{array}$ & $\begin{array}{r}0.040 \\
\pm 0.009\end{array}$ & $\begin{array}{l}42 \cdot 7 \\
\pm 7 \cdot 6\end{array}$ & $\begin{array}{r}1.8 \\
\pm 0.7\end{array}$ & $\begin{array}{r}0.082 \\
\pm 0.024\end{array}$ & $\begin{array}{r}0.046 \\
\pm 0.006\end{array}$ & $\begin{array}{l}34 \cdot 3 \\
\pm 11 \cdot 2\end{array}$ & $\begin{array}{l}1.7 \\
\pm 1 \cdot 0\end{array}$ \\
\hline Hydroxybutyrate & $\begin{array}{r}0.203 \\
\pm 0.039\end{array}$ & $\begin{array}{r}0.128 \\
\pm 0.028\end{array}$ & $\begin{array}{l}40.5 \\
\pm 4.6\end{array}$ & $\begin{array}{r}6.2 \\
\pm 1.3\end{array}$ & $\begin{array}{r}0.193 \\
\pm 0.041\end{array}$ & $\begin{array}{r}0.118 \\
\pm 0.026\end{array}$ & $\begin{array}{l}36.5 \\
\pm 8.3\end{array}$ & $\begin{array}{r}6.2 \\
\pm 1.3\end{array}$ & $\begin{array}{r}0.234 \\
\pm 0.045\end{array}$ & $\begin{array}{r}0.173 \\
\pm 0.030\end{array}$ & $\begin{array}{l}29 \cdot 2 \\
\pm 4 \cdot 7\end{array}$ & $\begin{array}{r}6.2 \\
\pm 2.0\end{array}$ \\
\hline Acetoacetate & $\begin{array}{r}0.109 \\
\pm 0.023\end{array}$ & $\begin{array}{r}0.063 \\
\pm 0.011\end{array}$ & $\begin{array}{l}35 \cdot 0 \\
\pm 7 \cdot 5\end{array}$ & $\begin{array}{r}5 \cdot 2 \\
\pm 1 \cdot 7\end{array}$ & $\begin{array}{r}0.127 \\
\pm 0.025\end{array}$ & $\begin{array}{r}0.061 \\
\pm 0.009\end{array}$ & $\begin{array}{l}44 \cdot 7 \\
\pm 8 \cdot 0\end{array}$ & $\begin{array}{c}7 \cdot 5 \\
\pm 2 \cdot 2\end{array}$ & $\begin{array}{r}0.149 \\
\pm 0.024\end{array}$ & $\begin{array}{r}0.097 \\
\pm 0.020\end{array}$ & $\begin{array}{l}34.5 \\
\pm 8.0\end{array}$ & $\begin{array}{r}6.0 \\
\pm 1.8\end{array}$ \\
\hline Free fatty acids & $\begin{array}{r}0.673 \\
\pm 0.070\end{array}$ & $\begin{array}{r}0.509 \\
\pm 0.067\end{array}$ & $\begin{array}{l}22.6 \\
\pm 3.7\end{array}$ & $\begin{array}{l}72 \cdot 5 \\
\pm 9 \cdot 8\end{array}$ & $\begin{array}{r}0.779 \\
\pm 0.073\end{array}$ & $\begin{array}{r}0.670 \\
\pm 0.073\end{array}$ & $\begin{array}{l}19 \cdot 0 \\
\pm 2.4\end{array}$ & $\begin{array}{l}74.4 \\
\pm 18.8\end{array}$ & $\begin{array}{r}0.781 \\
\pm 0.081\end{array}$ & $\begin{array}{r}0.640 \\
\pm 0.093\end{array}$ & $\begin{array}{l}24 \cdot 2 \\
\pm 7 \cdot 0\end{array}$ & $\begin{array}{l}106.8 \\
\pm 28.9\end{array}$ \\
\hline Glycerol & $\begin{array}{r}0.084 \\
\pm 0.012\end{array}$ & $\begin{array}{r}0.070 \\
\pm 0.014\end{array}$ & $\begin{array}{l}20.9 \\
\pm 5.3\end{array}$ & - & $\begin{array}{r}0.078 \\
\pm 0.012\end{array}$ & $\begin{array}{r}0.068 \\
\pm 0.012\end{array}$ & $\begin{array}{l}18 \cdot 0 \\
\pm 5 \cdot 7\end{array}$ & - & $\begin{array}{r}0.063 \\
\pm 0.008\end{array}$ & $\begin{array}{r}0.055 \\
\pm 0.008\end{array}$ & $\begin{array}{l}15.9 \\
\pm 5.0\end{array}$ & - \\
\hline
\end{tabular}

Values expressed as mean \pm SEM.

(A) Arterial concentration ( $\mathrm{mm} / \mathrm{l})$; (CS) coronary sinus concentration ( $\mathrm{mm} / \mathrm{l})$; ER extraction ratio (\%); OER oxygen extraction ratio (\%).

The effects of nitroprusside infusion upon myocardial substrate extraction are summarised in Table 2. Drug administration was without significant effect upon the arterial concentration, extraction ratio, or oxygen extraction ratio of any of the substrates measured. Of the five patients with coronary artery disease, one was producing lactate in the control period (extraction ratio $-5 \cdot 5 \%$ ), but during nitroprusside infusion extraction ratio rose to $+6.5 \%$. Despite the pronounced fall in coronary sinus flow, nitroprusside did not provoke lactate production or angina in any of the patients with coronary artery disease. At the highest dose of nitroprusside, however, one patient with congestive cardiomyopathy produced lactate (ER $-2 \%)$. This was not associated with angina or electrocardiographic abnormalities. The total of the oxygen extraction ratios was similar before and during both infusion rates of nitroprusside, $113 \% \pm 13,118 \% \pm 21$, and $146 \% \pm 33$.

\section{Discussion}

Sodium nitroprusside relaxes vascular smooth muscle, ${ }^{3}$ and as it has no direct effect upon the myocardium ${ }^{19}$ changes in cardiac performance during its administration are the result of alteration of loading conditions. Muscle tension, which depends upon both ventricular pressure and volume, is the load opposing myocardial contraction. ${ }^{20}$ As muscle tension changes throughout systole its mean value may be the best measure of load in the intact ventricle, ${ }^{20}$ and myocardial oxygen consumption will relate closely to load so defined. ${ }^{2021}$ At constant heart rate and inotropic state the direction of change in tension can be inferred from changes in ventricular systolic and diastolic pressures, and in myocardial oxygen consumption.
Load is not determined in a simple way by arterial or venous tone. For example, the fall in ventricular systolic pressure, and hence load, caused by a given reduction of peripheral resistance will depend upon the resulting change in stroke volume. In addition, the change in cardiac performance consequent upon load reduction will depend upon the initial load. ${ }^{8}$ Thus, the effect of vasodilators upon the heart is not readily predictable. For this reason we studied only patients with severe heart failure and gross ventricular dilatation, and found that each patient had a similar response to nitroprusside.

Infusion of $55 \mu \mathrm{g} / \mathrm{min}$ of nitroprusside reduced left ventricular systolic and end-diastolic pressure and myocardial oxygen consumption without significant change in heart rate or indices of contractility, which suggest that load decreased. Venous relaxation, which redistributes blood volume away from the heart, is the likely explanation for the large reduction in enddiastolic pressure. ${ }^{22}$ Despite this fall there was a small, but significant increase in output. When the infusion rate was doubled to $110 \mu \mathrm{g} / \mathrm{min}$, heart rate and indices of contractility did not change significantly. There were only minor, insignificant further reductions in ventricular pressures and myocardial oxygen consumption, suggesting little, if any, further decrease in load, despite significant further reduction in peripheral resistance. Stroke volume increased substantially. These results illustrate two apparently different mechanisms by which nitroprusside improves the performance of the failing heart: a reduction of load and energy requirements with little gain in output at the lower dose, and increased stroke volume at constant load at the higher dose.

Afthough there was dose-dependent reduction of peripheral resistance by nitroprusside, ventricular 
pressure and load did not decrease further at the higher infusion rate. Peripheral resistance is the ratio of mean pressure to mean flow, and describes inadequately an arterial system in which the relation between pressure and flow depends upon resistance, capacitance, and the inertia of blood. ${ }^{20} 23$ When arterial resistance and capacitance are manipulated separately, ${ }^{24}$ reduction of resistance increases flow and decreases pressure, whereas increasing capacitance raises stroke volume by augmenting late systolic flow, with little effect upon pressure. ${ }^{24}$ In both cases calculated peripheral resistance falls, but only in the former do pressure and load decrease substantially. It is implicit in these observations that stroke volume depends upon both the load opposing contraction and the properties of the arterial system. Our results suggest that the large increase in stroke volume at the higher dose of nitroprusside was the result not of decreased load, but of a favourable change in arterial properties allowing greater ejection at the same mean load. Aortic impedance may describe arterial properties in a way that clarifies their effect upon ventricular performance. ${ }^{2023}$ Nitroprusside reduces aortic impedance, ${ }^{25}$ though in circumstances where pressure has fallen rather than flow has increased. ${ }^{25}$

The effect of sodium nitroprusside upon cardiac energetics can be examined by using Bing's method ${ }^{7}$ of estimating the overall efficiency of the heart, which relates external work to myocardial oxygen consumption. While there are objections to this method, ${ }^{26} 27$ the oxygen cost of external work is of clinical importance. External work does not determine myocardial oxygen consumption, but the two are related in the normal heart ${ }^{7}$ because a fairly constant proportion of wall tension is transformed into external work by the large reduction of cavity dimensions during systole. In our patients the pressure component of work (mean systolic pressure minus end-diastolic pressure) was similar in the control state and at each dose of nitroprusside, so that changes in stroke volume determined changes in external work. The oxygen cost of developing this pressure was reduced by nitroprusside because of decreases in ventricular volume and the absolute values of pressure. The gain in efficiency at the low dose was the result mainly of this reduction in myocardial oxygen consumption, whereas the further improvement at the higher dose was because of the increased external work consequent upon greater stroke volume.

Efficiency so defined bears a complex relation to load $^{8}$ : it is maximum at intermediate loads, falling steeply at high and low loads. ${ }^{80}$ In order to remain. efficient in different circumstances the normal heart maintains load within reasonable limits. The steep slope relating stroke volume to filling pressure, the Anrepp effect, and increased contractility all prevent dilatation and hence excessive load. In normal subjects isometric exercise increases heart rate, myocardial contractility, arterial pressure, and cardiac output without change in peripheral resistance. ${ }^{28}$ The increase work is performed at constant end-diastolic pressure. ${ }^{28}$ Myocardial oxygen consumption and external work increase in proportion ${ }^{29}$ so that efficiency does not decrease. In our patients the haemodynamic changes during isometric exercise when off nitroprusside were similar to those reported previously in patients with heart failure ${ }^{28} 29$; peripheral resistance increased and end-diastolic pressure rose in five of the six. Myocardial oxygen consumption increased proportionately more than external work, so there was a small, but significant decrease in efficiency. When exercise was performed during nitroprusside infusion myocardial oxygen consumption increased substantially even though heart rate and peripheral resistance did not increase significantly, and there was only a small increase in systolic pressure. Though isometric exercise may decrease ventricular distensibility, ${ }^{30}$ the large rises in end-diastolic pressure and oxygen consumption suggest that the ventricle dilated in response to exercise. External work decreased insignificantly, and efficiency fell by nearly half. Thus, though initially higher on nitroprusside, efficiency decreased proportionately more during exercise than before the drug. These results show how precarious and sensitive to increased load is the improvement in efficiency caused by nitroprusside.

Conflicting results have been reported of the effects of nitroprusside upon myocardial ischaemia in patients with coronary artery disease. ${ }^{9} 10$ The large reduction in coronary flow during infusion of 55 $\mu \mathrm{g} / \mathrm{min}$ of nitroprusside did not provoke angina or lactate production in any patient, suggesting that it reflected decreased myocardial oxygen demand rather than inadequate perfusion pressure. The resting lactate production observed in one patient with coronary artery disease was abolished by nitroprusside infusion. It is unlikely, however, that the haemodynamic improvement during drug administration in the patients with coronary artery disease was the result of relief of ischaemia, as only one of them had metabolic evidence of ischaemia at rest, and comparable haemodynamic improvement was seen in the patients with congestive cardiomyopathy, each of whom had a high basal lactate extraction ratio.

One patient with cardiomyopathy produced lactate at the higher dose, but the significance of this is uncertain, as it was not associated with pain, electrocardiographic abnormalities, or haemodynamic deterioration. 
Nitroprusside caused no change in the extraction, extraction ratio, or oxygen extraction ratio of any substrate measured. The relation between oxygen uptake and substrate consumption did not change, and reduced substrate requirement was met by decreased coronary flow rather than by reduced extraction. The large improvements in efficiency were not associated with metabolic changes.

This study shows that nitroprusside has beneficial effects upon both stroke volume and myocardial energy requirements in patients with severe heart failure. At the lower dose the major effect was reduction of load and hence myocardial oxygen consumption, whereas at the higher dose stroke volume increased with little further change in load.

\section{References}

1 Chatteriee K. Vasodilator therapy for heart failure. Ann Intern Med 1975; 83: 421-3.

2 Chatterjee K, Parmley WW. Vasodilator treatment for acute and chronic heart failure. Br Heart $\mathcal{F}$ 1977; 39: 706-20.

3 Miller RR, Vismara LA, Zelis R, Amsterdam EA, Mason DT. Clinical use of sodium nitroprusside in chronic ischemic heart disease: effects on peripheral vascular resistance and venous tone and on ventricular volume, pump and mechanical performance. Circulation 1975; 51: 328-36.

4 Kovick RB, Tillisch JH, Berens SC, Bramowitz AD, Shine KI. Vasodilator therapy for chronic left ventricular failure. Circulation 1976; 53: 322-8.

5 Franciosa JA, Cohn JN. Hemodynamic responsiveness to short- and long-acting vasodilators in left ventricular failure. $A m \mathcal{F}$ Med 1978; 65: 126-33.

6 Meretoja OA, Laaksonen VO. Hemodynamic effects of preload and sodium nitroprusside in patients subjected to coronary bypass surgery. Circulation 1978; 58: 815-25.

7 Bing R. Cardiac metabolism. Physiol Rev 1965; 45: 171-213.

8 Ford LE. Effect of afterload reduction on myocardial energetics. Circ Res 1980; 46: 161-6.

9 Chiariello M, Gold HK, Leinbach RC, Davis MA, Maroko PR. Comparison between the effects of nitroprusside and nitroglycerin on ischemic injury during acute myocardial infarction. Circulation 1976; 54: 766-73.

10 Awan NA, Miller RR, Vera Z, DeMaria AN, Amsterdam EA, Mason DT. Reduction of S-T segment elevation with infusion of nitroprusside in patients with acute myocardial infarction. Am $\mathcal{f}$ Cardiol 1976; 38: 435-39.

11 Thompson DS, Naqvi N, Juul SM, Coltart DJ, Jenkins BS, Webb-Peploe MM. Haemodynamic and metabolic effects of atenolol in patients with angina pectoris. $\mathrm{Br}$ Heart f 1980; 43: 668-79.

12 Matthey DG, Chatterjee K, Tyberg JV, Lekven J, Brundage B, Parmley WW. Coronary sinus reflux: a source of error in the measurement of thermodilution coronary sinus flow. Circulation 1978; 57: 778-86.

13 Nakhjavan FK, Natarajan G, Smith AM, Dratch $M$, Goldberg H. Myocardial lactate metabolism during isometric handgrip test: comparison with pacing tachycardia. Br Heart $\mathcal{F}$ 1975; 37: 79-84.

14 Ganz W, Tamura K, Marcus HS, Donoso R, Yoshiaa S, Swan HJC. Measurement of coronary sinus blood flow by constant thermodilution in man. Circulation 1971; 44:181-95.

15 Hohorst HJ, Kreutz FH, Bücher T. Uber Metabolitgehalte und metabolit-konzentrationen in der Leber der Ratte. Biochemische Zeitschrift 1959; 332: 18-46.

16 Williamson DH, Mellanby J, Krebs HA. Enzymatic determination of $\mathrm{D}(-) \beta$-Hydroxybutyric acid and acetoacetate in blood. Biochem $\mathcal{F}$ 1962; 82: 90-6.

17 Kreutz FH. Enzymatische Glycerinbestimmung. Klin Wochenschr 1962; 40: 362-3.

18 Carruthers $M$, Young DAB. Free fatty acid estimation by a semi-automated fluorimetric method. Clin Chim Acta 1973; 49: 341-8.

19 Gmeiner R, Riedl J, Baumgartner H. Effect of sodium nitroprusside on myocardial performance and venous tone. Eur F Pharmacol 1975; 31: 287-91.

20 Noble MIM. Left ventricular load, arterial impedance and their interrelationship. Cardiovasc Res 1979; 13: 183-98.

21 Gibbs CL, Mommaerts WFMM, Ricchiuti NV. Energetics of cardiac contraction. F Physiol (Lond) 1967; 191: 25-46.

22 Pouleur H, Covell JW, Ross J, Jr. Effects of nitroprusside on venous return and central blood volume in the absence and presence of acute heart failure. Circulation 1980; 61: 328-37.

23 Milnor WR. Arterial impedance as ventricular afterload. Circ Res 1975; 36: 565-70.

24 Ishide N, Shimizu Y, Maruyama Y, et al. Effects of changes in the aortic imput impedance on systolic pressure-ejected volume relationships in the isolated supported canine left ventricle. Cardiovasc Res 1980; 14: $229-43$.

25 Gundel W, Cherry G, Rajagopalan B, Tan LB, Lee G, Schultz D. Aortic input impedance in man: acute response to vasodilator drugs (abstract). Clin Sci Mol Med 1979; 56: 4P.

26 Gibbs CL. Cardiac energetics. Physiol Rev 1978; 58: 174-254.

27 Wilkie DR. Thermodynamics and the interpretation of biological heat measurements. Progress in Biophysics and Biophysical Chemistry 1960; 10: 260-98.

28 Grossman W, McLaurin LP, Saltz SB, Paraskos JA, Dalen JE, Dexter L. Changes in the inotropic state of the left ventricle during isometric exercise. Br Heart $\mathcal{F}$ 1973; 35: 697-704.

29 Kivowitz C, Parmley WW, Donoso R, Marcus H, Ganz W, Swan HJC. Effects of isometric exercise on cardiac performance. Circulation 1971; 44: 994-1002.

30 Flessas AP, Connelly GP, Handa S, et al. Effects of isometric exercise on the end-diastolic pressure, volumes, and function of the left ventricle in man. Circulation 1976; 53: 839-47.

Requests for reprints to $\mathrm{Dr}$ D S Thompson, Department of Cardiology, St Thomas's Hospital, London SE1 7EH. 